\title{
Complement Biosynthesis by the Human Hepatoma-derived Cell Line HepG2
}

\author{
Katherine M. Morris, David P. Aden, Barbara B. Knowles, and \\ Harvey R. Colten, Children's Hospital Medical Center, Department of \\ Pediatrics, Division of Cell Biology, The Ina Sue Perlmutter Cystic Fibrosis \\ Research Center, Harvard Medical School, Boston, Massachusetts 02115; \\ Wistar Institute of Anatomy and Biology, Philadelphia, Pennsylvania 19104
}

\begin{abstract}
A в S T R A C T The human hepatoma-derived cell line, HepG2, synthesized and secreted functional complement proteins $\mathrm{Clr}, \mathrm{Cls}, \mathrm{C} 2, \mathrm{C} 3, \mathrm{C} 4, \mathrm{C} 5$, factor B, Cl inhibitor, C3b inactivator, a small amount of $\mathrm{C} 6$, and trace amounts of $\mathrm{C} 8$; but failed to produce detectable C1q, C7, or C9. Immunochemically, C2, C3, C4, C5, and $\mathrm{B}$ were isolated from culture medium as proteins with molecular sizes and subunit structures identical to the corresponding components isolated from serum. C2 and factor B from cellular lysates had slightly lower molecular weights than the corresponding proteins in culture medium. C3, C4, and C5 were detected as single chain precursor molecules in cellular lysates. These results demonstrate that human C5, like C3 and $\mathrm{C4}$, is synthesized as a single chain precursor that is converted by limited proteolysis to the native twochain molecule. It also establishes the precursor-product relationship for human pro-C4 and native $\mathrm{C4}$, pro$\mathrm{C} 5$, and native $\mathrm{C5}$.
\end{abstract}

\section{INTRODUCTION}

Clinically important changes in serum complement levels are associated with the acute phase response (1); several acquired diseases in which complement consumption, as well as synthesis, are presumably altered $(2,3)$; and genetic deficiencies of the complement proteins (4). Studies of the mechanisms accounting for these changes have been hampered by limited access to liver biopsy material. As early as 1900 Ehrlich and Morgenroth (5) suggested that complement was synthesized in the liver, and recently it was established that liver is the primary, if not the sole source of several serum complement components (reviewed in 6). After

Dr. Aden is the recipient of a Research Career Development Award from the American Cancer Society, CA00510.

Received for publication 13 April 1982. orthotopic liver transplantation from donors with distinct genetic variants of individual serum complement proteins, complete conversion from recipient to donor allotype was noted. This means that the liver is the source of at least $90 \%$ of the C3, C6, C8, and factor B contained in serum. Further support for the thesis that the liver is a site of complement synthesis was obtained in studies of primary cultures of human fetal and adult liver (mixed cell type and tissue slices) (7) and in several rat hepatoma cell strains (8).

On the other hand, considerable data indicating extrahepatic complement synthesis have been accumulated. Macrophages and monocytes synthesize $\mathrm{Cl}, \mathrm{C2}$, C3, C4, C5, and factor B (reviewed in 9); fibroblasts synthesize $\mathrm{Cl}$ and $\mathrm{C} 3(10,11)$; and epithelial cells produce $\mathrm{Cl}$ (12). It is probable that these cells are important for local complement production, though not as sources of complement in serum. There is direct evidence for structural, and possibly functional, differences between fibroblast $\mathrm{Clq}$ and the corresponding serum complement protein (13). For other components, notably $\mathrm{C} 2$ and $\mathrm{C} 4$, changes in local complement production by alveolar and peritoneal macrophages can be induced without affecting serum levels (14). Nonetheless, studies of complement production by monocytes and fibroblasts have been useful for initial investigations of human genetic disorders of complement production. Interpretation of these results has been limited by the fact that complement of extrahepatic origin contributes little to serum levels (6).

In the guinea pig $(15,16)$ and the mouse $(17,18)$ there is evidence that several multichain complement proteins are synthesized as single-chain precursor proteins. For the corresponding human complement proteins, the availability of a hepatoma-derived cell line HepG2 (19) permitted a similar analysis of the precursor, human pro-C3. That work established that human serum C3 is synthesized as a single-chain pre- 
cursor protein, which is converted by limited proteolysis to native functional C3 (20). The present study was undertaken to ascertain whether this well differentiated human hepatoma, HepG2, is suitable for studies of the biosynthesis of other human complement proteins and to investigate the details of their translation, posttranslational processing, and secretion.

\section{METHODS}

Medium and reagents. Minimal essential medium (MEM), ${ }^{1}$ Earle's salts and MEM lacking L-methionine, fetal bovine serum, sheep erythrocytes, and trypsin-versene were purchased from M. A. Bioproducts, Walkersville, MD. Complement proteins were purchased from Cordis Laboratories Inc., Miami, FL, or were purified from human plasma by the method of Hammer et al. (21) and Bing et al. (22). Purified $\mathrm{C} 3 \mathrm{~b}$ inactivator $(\mathrm{I})$, and $\beta \mathrm{IH}(\mathrm{H})$ were a gift from $\mathrm{Dr}$. Alvin E. Davis III, Boston, MA; and Clq, Clr, and Cls were a gift from Dr. David H. Bing, Boston, MA. L- $\left[{ }^{35} S\right]$ Methionine $(\sim 1,000 \mathrm{Ci} / \mathrm{mM})$ and a mixture of $\left[{ }^{14} \mathrm{C}\right]$ methylated-mol wt markers were purchased from Amersham Corp., Arlington Heights, IL. Acrylamide and sodium dodecyl sulfate (SDS) were purchased from Bio-Rad Laboratories Inc., Rockville Centre, NY. IgG-Sorb was purchased from the Enzyme Center, Cambridge, MA.

Antisera and antigens. Goat antisera to human C3, C4, factor $\mathrm{B}, \mathrm{Clq}, \mathrm{Clr}$, and $\mathrm{Cls}$ were obtained from Atlantic Antibodies, Inc., Westbrook, ME. Rabbit antiserum to human C2 was obtained from Seward Labs, London, England. Goat antiserum to human C5 was kindly provided by $\mathrm{Dr}$. Brian Tack, Boston, MA, and rabbit antiserum to human C5 by Dr. Richard Harrison, Medical Research Council, Cambridge, England. The globulin fraction of each antiserum was obtained by chromatography on Affi-gel blue (Pharmacia Fine Chemicals, Div., Piscataway, NJ). Purified C3, C5, and B (21) were used as carrier proteins. Equivalence was determined as previously described (12).

Culture conditions for medium collection and radiolabeling. HepG2, a human hepatoma-derived cell line that secretes numerous plasma proteins (23), was grown to confluence $\left(\sim 2 \times 10^{7}\right.$ cells $/ 75 \mathrm{~cm}^{2}$ flask) in MEM with $10 \%$ fetal bovine serum. Before labeling or collection of medium for functional assays, the monolayers were washed three times with $15 \mathrm{ml}$ MEM. For functional assays, cells were grown in $10 \mathrm{ml}$ MEM. At $8,24,48$, and $96 \mathrm{~h}$, a $200-\mu \mathrm{l}$ aliquot was removed from one set of cultures whereas in another set, the medium was removed and replaced with $10 \mathrm{ml}$ of fresh MEM. All media samples were stored at $-70^{\circ}$ until assayed. The cells were incubated in $4 \mathrm{ml}$ of MEM lacking methionine and containing $250 \mu \mathrm{Ci}$ of $\mathrm{L}-\left[{ }^{35} \mathrm{~S}\right] \mathrm{methionine} / \mathrm{ml}$. For kinetic studies, replicate cultures were labeled for $30 \mathrm{~min}$, the medium removed, and the monolayers rinsed three times in MEM; $4 \mathrm{ml}$ MEM were then added to the cultures. Cells from one culture were dissociated by trypsinization $(0.25 \%$ trypsin-0.1\% EDTA in phosphate-buffered saline), and washed 3 times in $15 \mathrm{ml}$ MEM. At $30,60,120,240$, and in some cases, $360 \mathrm{~min}$, medium was removed and frozen, and the monolayer was treated as above. The cells were lysed by the addition (while vortexing) of $4 \mathrm{ml} 0.5 \%$ Triton X-100;

${ }^{1}$ Abbreviations used in this paper: Eff Mol, effective molecule; INH, inhibitor; MEM, minimum essential medium; PAGE, polyacrylamide gel electrophoresis; VBS, veronalbuffered saline.
$10 \mathrm{mM}$ sodium phosphate; $150 \mathrm{mM} \mathrm{NaCl} ; 10 \mathrm{mM}$ EDTA; $2 \mathrm{mM}$ phenyl methyl sulfonic fluoride, $\mathrm{pH} 7.6$; and a freezethaw cycle. After centrifugation for $30 \mathrm{~min}$ at $15,000 \mathrm{~g}$, the supernatant fluids were removed and frozen at $-70^{\circ}$ in $1-\mathrm{ml}$ aliquots until use. TCA-precipitable protein in the media and lysates was determined as described (24).

Assay of medium for complement function. For assay of the functional activity of each component, a dilution of culture medium was made in isotonic veronal-buffered saline (VBS) sucrose with gelatin, calcium, and magnesium, pH 7.35 (VBS sucrose) for $\mathrm{Cl}, \mathrm{Clq}, \mathrm{Clr}, \mathrm{Cls}, \mathrm{C4}, \mathrm{C} 2$, and $\mathrm{Cl}$ inhibitor (INH) and in VBS with dextrose, magnesium, calcium, and gelatin, $\mathrm{pH} 7.35$ (VBS-dextrose) for $\mathrm{C} 3, \mathrm{C} 5, \mathrm{C} 6$, $\mathrm{C} 7, \mathrm{C} 8, \mathrm{C} 9$, and B. Assays for $\mathrm{Cl}, \mathrm{C} 2, \mathrm{C} 4$, and $\mathrm{Cl} \mathrm{INH}$ components were done essentially as outlined by Rapp and Borsos (25) and for C3 as modified by Colten et al. (26) and factor B by Beatty et al. (27). Clq, Clr, and Cls assays were adapted from the $\mathrm{Cl}$ assay (25) using purified $\mathrm{Cl}$ subcomponents and EA as indicator cells for Clq and EAClq4 for $\mathrm{Clr}$ and $\mathrm{Cls}$ assays. Effective molecules (Eff $\mathrm{Mol}$ ) of each component were calculated by the method outlined by Rapp and Borsos (25). These assays are capable of detecting $<100$ $\mathrm{pg} / \mathrm{ml}$ of functional complement components with an error of $\pm 5 \%$. The efficiency of the hemolytic assays for serum $\mathrm{C} 3$, $\mathrm{C} 2$, and $\mathrm{C} 4$ were estimated. The efficiency of detection was $1 \%$ for $\mathrm{C} 3,3.1 \%$ for $\mathrm{C} 2$, and $73 \%$ for $\mathrm{C} 4$. These values agree with those previously published for C2 and C4 (28) and C3 (29).

To determine if newly synthesized C 3 is cleaved by C3b inactivator in a manner analogous to serum C3 (30), and to assay for inactivator function in conditioned medium, the following experiment was done. The amount of protein in cellular lysates and culture media was estimated by absorbance ${ }_{280}^{1 \%}$ of dilutions of each. C3b was produced by treatment of media and lysates with L-1-tosylamide-2-phenylethylchloromethyl ketone-trypsin. Aliquots of medium or lysate with a known protein concentration were brought to $22^{\circ} \mathrm{C}$ and then an amount of L-1-tosylamide-2-phenylethylchloromethyl ketone-trypsin $(1 \mathrm{mg} / \mathrm{ml})$ was added to equal $1 \%$ of the total protein in the lysate or medium. After $3 \mathrm{~min}$ at $22^{\circ} \mathrm{C}$ the trypsin was inactivated by addition of a twofold excess of soybean trypsin inhibitor. After centrifugation for $5 \mathrm{~min}$ at $15,000 \mathrm{~g}$, aliquots of the trypsin-treated and untreated media and lysates were transferred to $1.5 \mathrm{ml}$ Beckman centrifuge tubes (Beckman Instruments, Inc., Spinco Div., Palo Alto, CA). Enough purified C3b inactivator, alone, or with $\beta \mathrm{IH}$ were added so that the concentration of each was equivalent to $5 \%$ of the protein content of the lysates or media. These were vortexed and incubated for $2 \mathrm{~h}$ at $37^{\circ} \mathrm{C}$. C 3 was then precipitated from each sample and analyzed by SDS-polyacrylamide gel electrophoresis (PAGE) (31) as described.

Immunoprecipitation of complement components from medium and intracellular lysates. Cellular lysates and culture medium (made $2 \mathrm{mM}$ in phenyl methyl sulfonic fluoride with a $200-\mathrm{mM}$ phenyl methyl sulfonic fluoride stock in absolute ethanol, $0.5 \%$ in Triton X-100 and deoxycholate using $2.5 \%$ Triton $\mathrm{X}-100,2.5 \%$ deoxycholate, $10 \mathrm{mM}$ sodium phosphate, $150 \mathrm{mM} \mathrm{NaCl}, \mathrm{pH} \mathrm{7.6}$; and $10 \mathrm{mM}$ in EDTA with a $200-\mathrm{mM} \mathrm{pH} 7.6$ stock) were centrifuged at $15,000 \mathrm{~g}$ for $5 \mathrm{~min}$ before measured aliquots were removed to new tubes.

For precipitations using purified proteins as carrier, an amount of antibody was added to the lysates or media to yield a twofold antibody excess and an amount of antigen to yield $30 \mu \mathrm{g}$ of protein in the precipitate at equivalence. Mixtures were incubated for $1.5 \mathrm{~h}$ at room temperature if the total volume was $<200 \mu \mathrm{l}$, and $3 \mathrm{~h}$ for volumes to 800 
$\mu l$. The immune precipitates were washed three times in $0.5 \%$ Triton X-100, $0.5 \%$ deoxycholate, $10 \mathrm{mM}$ sodium phosphate, $150 \mathrm{mM} \mathrm{NaCl}, 10 \mathrm{mM}$ EDTA, pH 7.6; once in 150 $\mathrm{mM} \mathrm{NaCl}$, and once in acetone. The acetone was removed in vacuo and the pellets were dissolved in Laemmli sample buffer (31) for SDS-PAGE (31) as described below.

For precipitation by binding to staphylococcal protein $\mathrm{A}$, 5-10 $\mu$ l of antiserum were added to the 50-200 $\mu$ l of cell lysate or medium and incubated at $4^{\circ} \mathrm{C}$ overnight. $50 \mu \mathrm{l}$ of a washed $10 \%$ suspension of IgG-Sorb in $1 \mathrm{mg} / \mathrm{ml}$ bovine serum albumin in a pH 7.6 phosphate-buffered saline buffer containing $0.5 \%$ deoxycholate (wt/vol) and $0.5 \%$ Triton $\mathrm{X}$ 100 was added and incubated for $60 \mathrm{~min}$ at $4^{\circ} \mathrm{C}$. Pellets were washed six times in the above buffer (without bovine serum albumin), resuspended in Laemmli sample buffer (31), boiled for $3 \mathrm{~min}$, and centrifuged $2 \mathrm{~min}$ at $15,000 \mathrm{~g}$. The supernatant was removed to a new tube for SDS-PAGE (31) as described below. Normal goat or rabbit serum was used in place of the antiserum for control immunoprecipitates.

SDS-PAGE. The method of Laemmli (31) was used for electrophoresis in $9 \%$ polyacrylamide slab gels. Samples were reduced with dithiothreitol $(50 \mathrm{mM}$ final concentration in sample buffer) or 2-mercaptoethanol by boiling for $2 \mathrm{~min}$. A radioactive mol wt standard was included on each gel. After electrophoresis the gel was stained with Coomassie Brilliant Blue, destained, impregnated with PPO (En ${ }^{3}$ Hance or Autofluor), and dried. Autoradiograms were produced using Kodak XAR X-ray film (Eastman Kodak Co., Rochester, NY).

\section{RESULTS}

Production of functional complement component activity. Functional C2, C3, C4, C5, C6, C1INH, and $\mathrm{B}$ were detected in HepG2 culture medium at 6 and $96 \mathrm{~h}$, respectively, when the medium was changed at 8 and $24 \mathrm{~h}$ intervals, thereafter (Table I, columns 2 and 3). Functional Clr and Cls, but not Clq, were detected in medium that was sampled but not changed throughout the 96-h incubation (Fig. 1). Cl, Clq, C7, and C9 were not detected at 6 or $96 \mathrm{~h}$, but a small amount of functional C8 was present at $96 \mathrm{~h}$. Net pro-
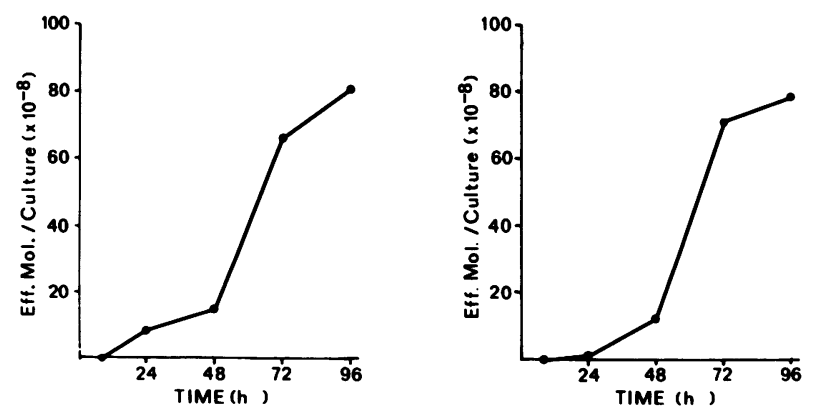

Figure 1 Secretion of hemolytically active Clr and Cls by HepG2 cells. Replicate cultures $\left(\sim 2 \times 10^{7}\right.$ cells/cultures) were incubated for $96 \mathrm{~h}$ in $10 \mathrm{ml}$ of MEM and $200 \mu \mathrm{l}$ samples were withdrawn at $8,24,48,72$, and $96 \mathrm{~h}$. Left panel: $\mathrm{Clr}$ activity was assayed by the addition of purified $\mathrm{Cl} \bar{s}$ to EAClq indicator-cells. Right panel: Cls activity was assayed by the addition of purified $\mathrm{Cl} \overline{\mathbf{r}}$ to EAClq indicator cells.
TABLE I

Functional Complement Component Activity in HepG2 Extracellular Medium and Normal Human Serum

\begin{tabular}{lccc}
\hline & & \multicolumn{2}{c}{$\begin{array}{c}\text { HepG2t } \\
\text { Eff Mol/4 ml culture }\end{array}$} \\
\cline { 3 - 4 } Components & NHS & & $96 \mathrm{~h} \S$ \\
\hline & $\times 10^{-12}$ & & $\times 10^{-8}$ \\
& & $h$ & $h$ \\
C1 & 33.0 & 0 & 0 \\
C2 & 4.4 & 344.5 & $2,337.3$ \\
C3 & 1.9 & 8.2 & 157.0 \\
C4 & 94.0 & 87.5 & 831.3 \\
C5 & 2.7 & 49.1 & $1,892.0$ \\
C6 & 4.3 & 1.2 & 49.3 \\
C7 & 1.1 & 0 & 0.3 \\
C8 & 8.0 & 0 & 2.5 \\
C9 & 3.1 & 0 & 0 \\
C1 INH & 2.5 & 82.1 & $2,462.6$ \\
B & 52.1 & 40.0 & 496.5 \\
\hline
\end{tabular}

- A normal human serum (NHS) was assayed at same time to assure the validity of the assay. Each value was within the normal range established for this laboratory.

$\downarrow$ Values given represent the average of three or four separate experiments.

$\S$ Results at $96 \mathrm{~h}$ were derived from cumulative activities in culture media harvested at 24-h intervals. At these intervals, the cells were refed with $10 \mathrm{ml}$ of fresh medium as described in Methods.

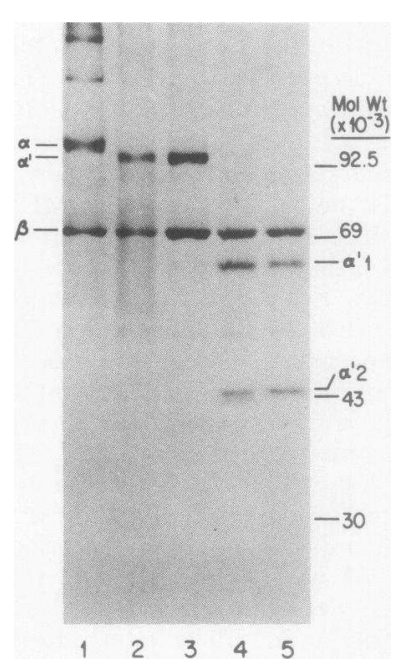

Figure 2 C3b inactivator cleavage of C3 from HepG2 medium. C3 (lane 1) was cleaved by trypsin to yield C3b (lane 2). Addition of purified C3b inactivator yielded no cleavage of the $\alpha^{\prime}$ chain (lane 3 ) whereas purified $\beta$ IH alone (lane 4) or $\beta \mathrm{IH}$ plus purified $\mathrm{C} 3 \mathrm{~b}$ inactivator (lane 5 ) caused the cleavage of $\alpha^{\prime}$ to two major subunits of approximate mol wt of 67,000 and 46,000 . A minor product $(43,000)$ can also be observed in lane 4. 
duction of active C2 exceeded factor B by $\sim 8.6$-fold at $6 \mathrm{~h}$ and 4.7 -fold by $96 \mathrm{~h}$. When the efficiency of hemolytic assays for C3 (29) and C4 (28) were taken into account, the amount of $\mathrm{C} 3$ protein in the medium exceeded C4 by 6.8-fold at $6 \mathrm{~h}$ and 13.9-fold at $96 \mathrm{~h}$
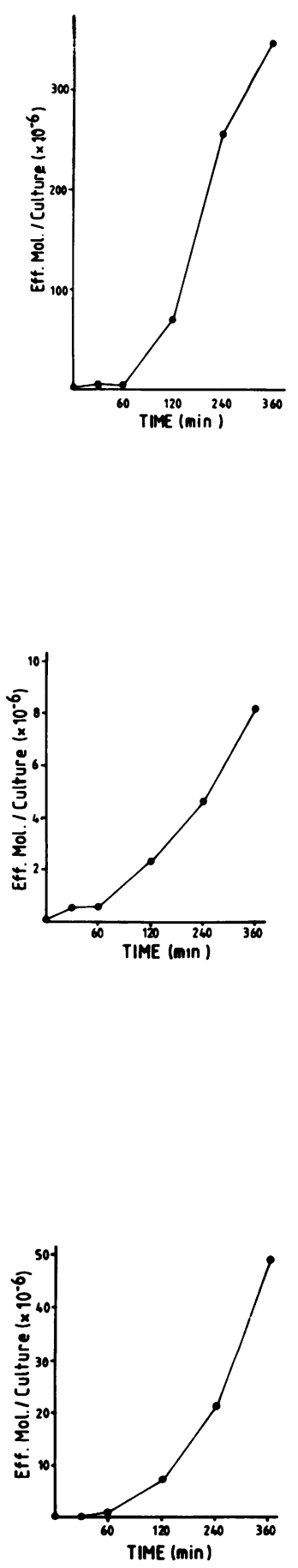

A

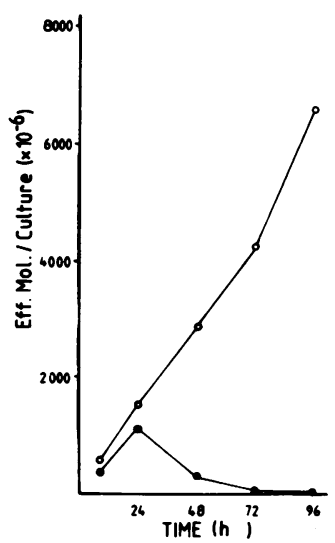

C

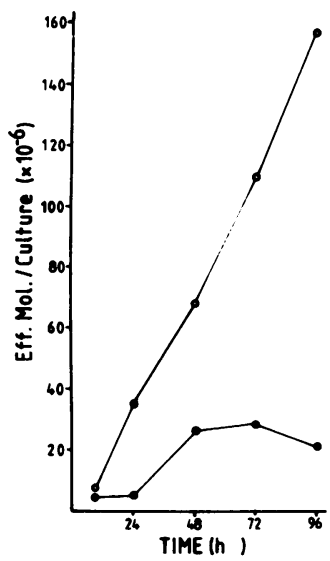

$\mathbf{E}$

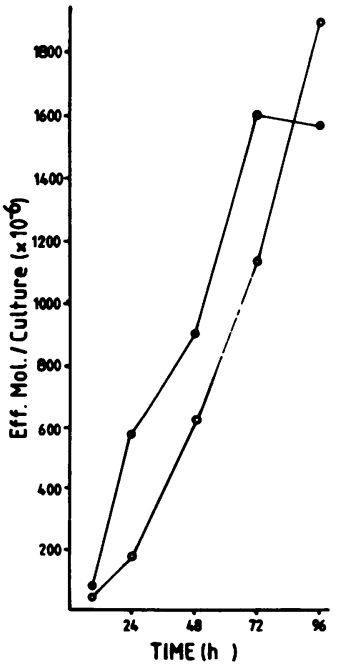

(i.e., although the ratio of functional C3:C4 detected in the medium was $\sim 1: 10$, the ratio of the efficiency of the C3:C4 hemolytic assay is $\sim 75: 1$ ). Evidence for the secretion of biologically active $\mathrm{C} 3 \mathrm{~b}$ inactivator by HepG2 is shown in Fig. 2, which demonstrates cleav-

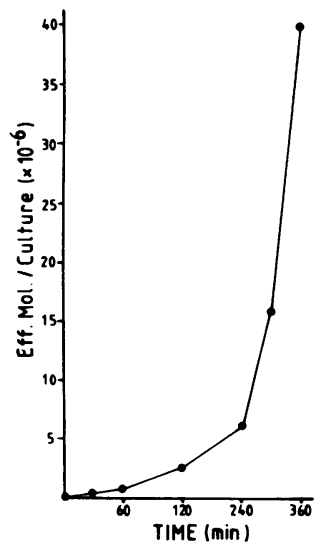

B

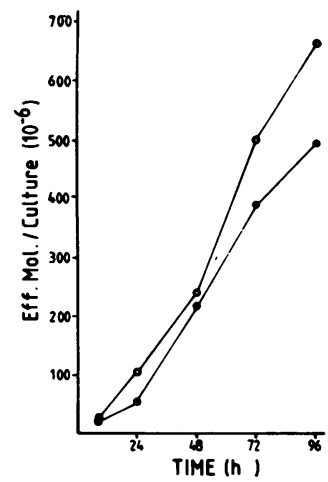

D

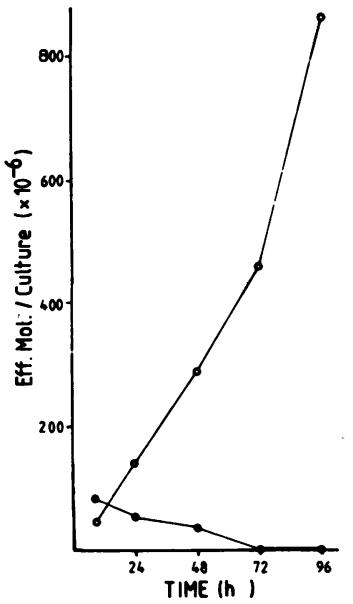

Figure 3 (A) Secretion of hemolytically active C2 by HepG2 cells. Left panel: Replicate cultures $\left(\sim 2 \times 10^{7}\right.$ cells culture) were incubated for $30,60,120,240$, and $360 \mathrm{~min}$. Right panel: Individual cultures were incubated for $96 \mathrm{~h}$ with either $10 \mathrm{ml}$ of medium completely replaced at 8 and $24 \mathrm{~h}$, and 24-h intervals thereafter, (open circles) or 200 $\mu$ l samples of medium $(10 \mathrm{ml})$ (no replacement) withdrawn at $8,24,48,72$, and $96 \mathrm{~h}$ (closed circles). (B) Secretion of hemolytically active factor B by HepG2 cells. Same protocol as Fig. 3A. (C) Secretion of hemolytically active C3 by HepG2 cells. Same protocol as Fig. 3A. (D) Secretion of hemolytically active C4 by HepG2 cells. Same protocol as Fig. $3 \mathrm{~A}$. (E) Secretion of hemolytically active C5 by HepG2 cells. Same protocol as Fig. 3A. 
age of $\mathrm{C} 3 \mathrm{~b}$ to $\mathrm{C} 3 \mathrm{c}$ and $\mathrm{C} 3 \mathrm{~d}$, after the addition of $\beta \mathrm{IH}$ to conditioned medium (lane 4).

Studies of the kinetics of secretion of functional complement proteins, factor B, C2, C3, C4, and C5, demonstrated that these components could be detected in culture media within $60 \mathrm{~min}$ (Fig. 3A-E, left-hand panels). Analysis of long-term cultures indicated that if the media were not changed throughout the $96-\mathrm{h}$ period, functional activity of $\mathrm{C} 2$ and $\mathrm{C} 4$ decreased at later time periods (Fig. 3A-E, right-hand panels). Recovery of functional C3 plateaued at 72-96 h. Only C5 and B function were unaffected by the sampling procedure. The possibility was considered that the instability of $\mathrm{C} 2$, and $\mathrm{C} 4$ or apparent lack of or low synthesis of $\mathrm{C} 6, \mathrm{C} 7$, and $\mathrm{C} 9$ was the result of degradation. Purified C4, C6, C7, and C9 were added to 96h sampled culture media (conditioned medium) and incubated at $37^{\circ} \mathrm{C}$ for $24 \mathrm{~h}$. C4 activity decreased but C6, C7, and C9 were stable (data not shown).

Isolation of complement proteins from cellular lysates and culture medium. SDS-PAGE analysis under reducing conditions of immunoprecipitates of $\mathrm{C} 3, \mathrm{C4}$, and $\mathrm{C} 5$ showed radiolabeled bands at $\sim 180,000$, 190,000 , and 180,000 daltons, respectively in intracellular lysates (Fig. 4). The corresponding extracellular complement proteins in the medium had sizes and subunit structures that were identical with $\mathrm{C} 3, \mathrm{C4}$, and $\mathrm{C} 5$ purified from serum i.e., the radiolabeled bands comigrated with the polypeptides from the pro-

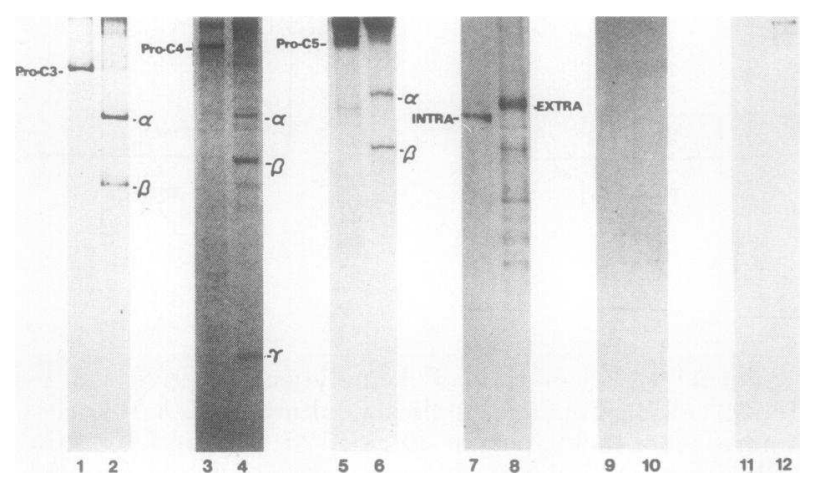

Figure 4 Complement biosynthesis by the human hepatoma-derived cell line HepG2. An autoradiogram of SDSPAGE analysis under reducing conditions of $\mathrm{C} 3, \mathrm{C4}, \mathrm{C} 5$, factor B, ovalbumin (control) and normal goat serum (control) from HepG2 lysates (odd numbers) and media (even numbers) is shown. Cells were incubated for $5 \mathrm{~h}$ with 250 $\mu \mathrm{Ci} / \mathrm{ml}$ of $\mathrm{L}-\left[{ }^{35} \mathrm{~S}\right]$ methionine in $4 \mathrm{ml}$ of $\mathrm{L}$-methionine-free MEM. Lanes 1 and 2 represent Pro-C3 and C3; lanes 3 and 4, Pro-C4 and C4; lanes 5 and 6, Pro-C5 and C5; lanes 7 and 8 , intracellular factor $B$ and extracellular factor B; lanes 9 and 10, ovalbumin (used as a control for carrier-antibody precipitations); and lanes 11 and 12 , normal goat serum (used as a control for Staph A precipitation with goat antibodies).

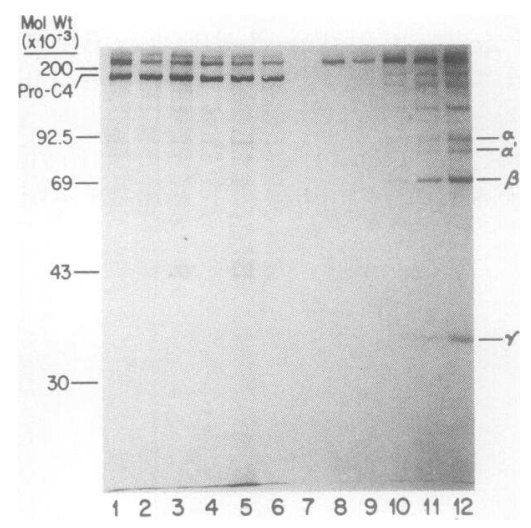

FIgure 5 Kinetics of pro-C4 synthesis and secretion by HepG2. An autoradiogram of SDS-PAGE under reducing conditions of both pro-C4 isolated from cellular lysates; and C4 from media is shown. Replicate cultures of confluent HepG2 cells were pulsed for $30 \mathrm{~min}$ with $250 \mu \mathrm{Ci} / \mathrm{ml}$ of L$\left.{ }^{35} \mathrm{~S}\right] \mathrm{methionine}$ in $4 \mathrm{ml}$ of $\mathrm{L}$-methionine-free medium and then incubated for $0,30,60,120,240$, and $360 \mathrm{~min}$ in unlabeled L-methionine containing MEM. Lanes 1-6 contain the cell lysates corresponding to $0,30,60,120,240$, and 360 min post-chase, and lanes 7-12 contain the media from the same time points.

teins isolated from plasma. Intracellular factor B had an apparent mol wt of 89,000 ; slightly less than the extracellular protein $(92,000)$ (Fig. 4). Control immunoprecipitates subjected to the same analysis showed a band at 22,000 daltons but no labeled proteins with mobilities of the intra- or extracellular complement proteins.

Precursor-product relationship between pro-C4 and C4, pro-C5 and C5, intracellular and extracellular $B$ and intracellular and extracellular C2. To determine whether the intracellular single-chain C4 and C5 antigens were authentic precursors of the corresponding multichain proteins, a pulse-chase experiment was performed, the results of which are shown in Figs. 5 and 6. Similarly, the rates of factor B and C2 secretion were also obtained from this experiment (Figs. 7 and 8). After incubation of the cells for $30 \mathrm{~min}$ with medium containing L- $\left[{ }^{35}\right.$ S $]$ methionine, labeled pro-C4 (Fig. 5), pro-C5 (Fig. 6), intracellular B (Fig. 7), and intracellular C2 (Fig. 8) were detected in the cellular lysates. During the chase period, the gradual disappearance of each was accompanied by the appearance extracellularly of the native three-chain $\mathrm{C} 4$, two-chain $\mathrm{C} 5$, and factor $\mathrm{B}$ and $\mathrm{C} 2$. The rate of factor $\mathrm{B}$ secretion was similar to that of $\mathrm{C} 2$ secretion (Fig. 7 vs. Fig. 8). Two radiolabeled bands were precipitated from cellular lysate by antiserum to $\mathrm{C} 2$. The larger protein (mol wt 84,000) disappeared during the chase period concomitant with the appearance of radiolabeled C2 in the medium. A second protein ( $\mathrm{mol}$ wt 79,000$)$ re- 


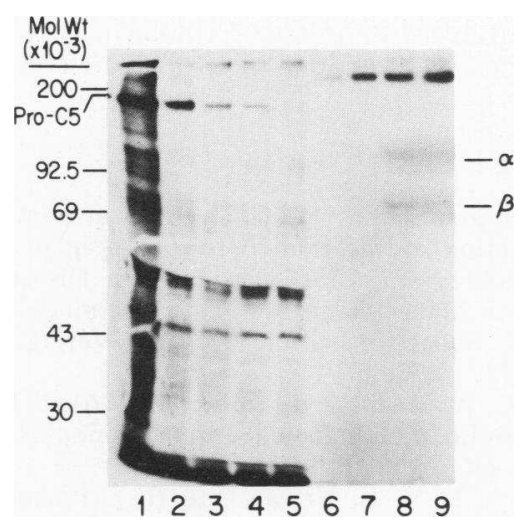

Figure 6 Kinetics of pro-C5 synthesis and secretion by HepG2. Same conditions as Fig. 5 except lanes 1-5, cellular lysates corresponding to $0,30,60,120$, and $240 \mathrm{~min}$ postchase, and lanes $6-9$, media corresponding to $30,60,120$, and $240 \mathrm{~min}$ post-chase.

mained cell-associated for $360 \mathrm{~min}$. The precipitation of each of the radiolabeled bands was blocked by the addition of unlabeled purified C2 protein (data not shown).

\section{DISCUSSION}

The capacity to easily and repeatedly obtain human monocytes, macrophages, and fibroblasts has led to the use of these cell types for in vitro studies of the biochemical basis of genetic and acquired disorders of complement biosynthesis. Limited access to liver, the major site of synthesis of several serum complement proteins, has made it difficult to ascertain whether the synthesis and postsynthetic events governing complement production are similar in hepatic and extrahepatic sites of complement biosynthesis. The develop-

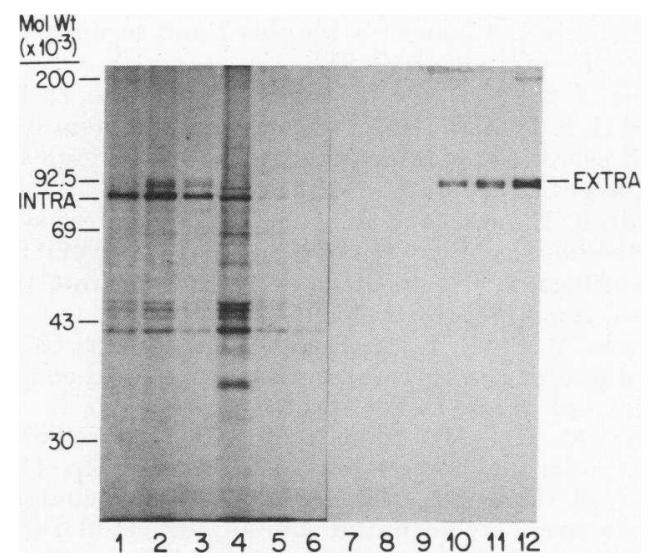

FIGURE 7 Kinetics of synthesis and secretion of factor B by HepG2. Same legend as Fig. 5.

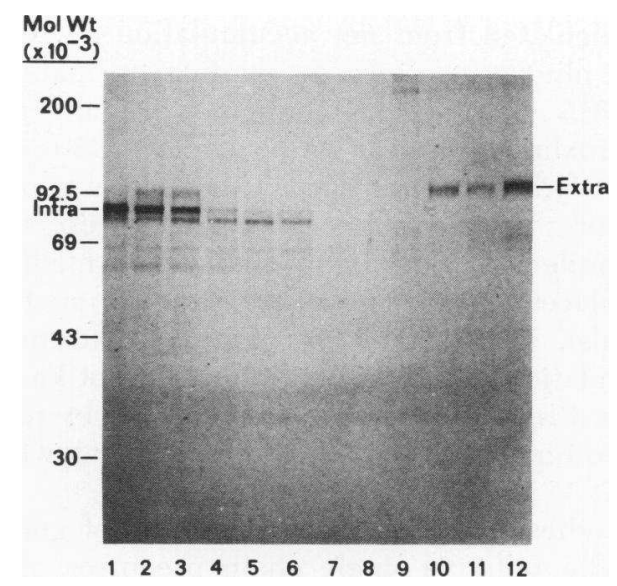

Figure 8 Kinetics of synthesis and secretion of $\mathrm{C} 2$ by HepG2. Same legend as Fig. 5.

ment of a well differentiated human hepatoma-derived cell line, HepG2, made it possible in the present study to examine these questions.

HepG2 synthesizes and secretes $\mathrm{Clr}, \mathrm{Cls}, \mathrm{C} 2, \mathrm{C} 3$, $\mathrm{C} 4, \mathrm{C} 5, \mathrm{C} 6$, factor $\mathrm{B}$, the $\mathrm{C} 3 \mathrm{~b}$ inactivator, $\mathrm{Cl}$ inhibitor, and trace amounts of C8. This conclusion was based on detection of the biologically active proteins in culture media and in the case of $\mathrm{C} 2, \mathrm{C} 3, \mathrm{C} 4, \mathrm{C} 5$, and factor $\mathrm{B}$, incorporation of ${ }^{35} \mathrm{~S}$-labeled methionine into proteins with sizes and subunit structures identical to the corresponding proteins in plasma. A 50 -fold concentrate of HepG2 medium labeled for $5 \mathrm{~h}$ with ${ }^{35} \mathrm{~S}$-methionine gave precipitin bands (visible on autoradiograms) in Ouchterlony analysis with antiserum to $\mathrm{Clr}$ and $\mathrm{Cls}$ but not with Clq (data not shown). No biologically active $\mathrm{Clq}, \mathrm{Cl}, \mathrm{C} 7$, or $\mathrm{C} 8$ were detected in culture medium from HepG2 even after $96 \mathrm{~h}$.

The rate of secretion of functional $\mathrm{C} 2$ exceeded the rate of factor B secretion by 5-10-fold. This is similar to the relative rates of secretion of these structurally and functionally analogous proteins in the human alveolar and breast milk macrophages (14). In contrast, the human peripheral blood monocyte secretes about equal amounts of $\mathrm{C} 2$ and factor $\mathrm{B}$ even after prolonged culture in vitro (14). The detection of functional and immunochemical Cls was particularly important because $\mathrm{C} 2$ and $\mathrm{C} 4$, the natural substrates of the $\mathrm{Cls}$ enzyme, were unstable in cultures maintained for 96 $\mathrm{h}$ without a medium change. Nevertheless, it was possible in short-term cultures (4-6 h), to estimate rates of secretion of functional $\mathrm{C} 2$ and $\mathrm{C} 4$, and, by introducing a complete medium change at 24 -h intervals, to study secretion over a 4 -d period. From the immunochemical evidence some $\mathrm{C} 4$ breakdown can be deduced by noting $\alpha^{\prime}$ chain of C4b in medium at 360 min after a pulse-chase (Fig. 5). Thus the secretion 
rate calculated from net accumulation of active C4 and $\mathrm{C} 2$ must be considered a minimal estimate. Factor $B$ and C5 continued to accumulate in culture media at approximately linear rates, whereas C3 levels plateaued after $48 \mathrm{~h}$ in culture. This effect was observed in cultures from which small aliquots were removed for complement assays (i.e., when spent medium was not replaced completely with fresh medium at regular intervals). The reasons for different patterns of net accumulation of individual proteins is not known but the effect in each instance was abrogated by removing the medium at 24-h intervals and refeeding with fresh media.

In studies of the cell-free translation of guinea pig mRNA, a putative single chain precursor of native guinea pig C4 (pro-C4) was identified (15). Gorski and Muller Eberhard (32) and independently, Gigli (33) detected a similar protein in normal human plasma and suggested that perhaps this was human pro-C4. Formal proof of the precursor product relationship between single chain pro- $\mathrm{C} 4$ and $\mathrm{C} 4$ has been provided for the corresponding guinea pig (15) and mouse proteins (17) but not for human pro-C4. In addition, in experimental animals $(34,35)$ a precursor of native $C 5$ (pro-C5) was identified; but heretofore, human pro-C5 had not been described. Pulse-chase experiments with the HepG2 cells establish that human pro-C4, pro-C5 and pro-C3 (20) are authentic precursors of the corresponding multichain complement proteins. In guinea pig macrophage cultures $\mathrm{C} 2$ and factor $\mathrm{B}$ each undergo a two-step glycosylation sequence which results in recovery of a slightly smaller molecular weight protein intracellularly than is found in serum or extracellular medium (36). The data reported here suggest a similar postsynthetic process for human C2 and factor B. An additional cell-associated $\mathrm{C} 2$ protein was found in detergent lysates of HepG2. This protein, in contrast to the precursor of extracellular C2 proteins, failed to disappear from the cell compartment during a chase with unlabeled amino acids. This finding is similar to the report of membrane associated factor $B$ found in mouse macrophages (37). The role of these cell associated complement proteins remains to be established.

Altogether, these data demonstrate the utility of the HepG2 cell line for studies of the biosynthesis, posttranslational modification, and secretion of most of the proteins of the complement system.

\section{ACKNOWLEDGMENTS}

We thank Dr. Alvin E. Davis, III for the gift of purified C3b inactivator and $\beta I H$, Dr. Richard A. Harrison for rabbit antiserum to human C5, Dr. Brian F. Tack for goat antiserum to human C5, and Helen Hourihan for her excellent secretarial services.

This work was supported by U. S. Public Health grants
AI15033, HL22487, AM16392, CA25875, CA18470, and National Science Foundation grant PCM7900033.

\section{REFERENCES}

1. Schorlemmer, H. U. 1981. The role of complement in the function of the monocyte-macrophage system. In Haematology and Blood Transfusion. Disorders of the Monocyte Macrophage System. F. Schmalzl, D. Hahn, and H. E. Schaeffer, editors. Springer-Verlag, New York. 27: 59-71.

2. Alper, C. A., A. S. Levin, and F. S. Rosen. 1966. Beta1-C-globulin: metabolism in glomerulonephritis. Science (Wash., DC). 153: 180-182.

3. Rynes, R. I., R. E. Vrizar, and R. J. Pickering. 1977. Genetic deficiency of the second component of complement (C2) associated with lupus erythematosus. Am. J. Med. 63: 279-288.

4. Rosen, F. S. 1981. The primary immunodeficiencies and serum complement defects. In Hematology of Infancy and Childhood. D. G. Nathan and F. A. Oski, editors. W. B. Saunders Company, Philadelphia. 2: 866-886.

5. Ehrlich, P., and J. Morgenroth. 1900. Uber haemolysine. Klin. Wochenschr. 37: 453-458.

6. Alper, C. A., and F. S. Rosen. 1976. Genetics of the complement system. Adv. Hum. Genet. 7: 141-188.

7. Colten, H. R. 1976. Biochemistry of complement. Adv. Immunol. 22: 67-118.

8. Strunk, R. C., A. H. Tashjian, Jr., and H. R. Colten. 1975. Complement biosynthesis in vitro by rat hepatoma cell strains. J. Immunol. 114: 331-335.

9. Colten, H. R., Y. M. Ooi, and P. Edelson. 1979. Synthesis and secretion of complement proteins by macrophages. Ann. NY Acad. Sci. 332: 482-490.

10. Reid, K. B. M., and E. Solomon. 1977. Biosynthesis of the first component of complement by human fibroblasts. Biochem. J. 167: 647-660.

11. Stecher, V. J., and G. J. Thorbecke. 1967. Sites of synthesis of serum proteins III. Production of Blc/BlE and transferrin by primate and rodent cell lines. J. Immunol. 99: 660-668.

12. Morris, K. M., H. R. Colten, and D. H. Bing. 1978. The first component of complement. A quantitative comparison of its biosynthesis in culture by human epithelial and mesenchymal cells. J. Exp. Med. 148: 1007-1019.

13. Skot, J., E. Solomon, K. B. M. Reid, and R. A. Thompson. 1981. Distinct genes for fibroblast and serum Clq. $\mathrm{Na}$ ture (Lond.). 292: 549-551.

14. Cole, F. S., W. J. Matthews, Jr., J. T. Marino, D. J. Gash, and H. R. Colten. 1980. Control of complement synthesis and secretion in bronchoalveolar and peritoneal macrophages. J. Immunol. 125: 1120-1124.

15. Hall, R. E., and H. R. Colten. 1977. Cell-free synthesis of the fourth component of guinea pig complement (C4): identification of a precursor of serum C4 (Pro-C4). Proc. Natl. Acad. Sci. USA. 74: 1707-1710.

16. Brade, V. R., R. E. Hall, and H. R. Colten. 1977. Biosynthesis of pro-C3, a precursor of the third component of complement. J. Exp. Med. 146: 759-765.

17. Roos, M. H., J. P. Atkinson, and D. C. Shreffler. 1978. Molecular characterization of the Ss and Slp (C4) proteins of the mouse $\mathrm{H}-2$ complex: subunit composition, chain size, polymorphism, and an intracellular (pro-C4) precursor. J. Immunol. 121: 1106-1115.

18. Odink, K. G., G. Fey, K. Wiebauer, and H. Digglemann. 1981. Mouse complement components C3 and C4. Char- 
acterization of their messenger RNA and molecular cloning of complementary DNA for C3. J. Biol. Chem. 256: 1453-1458.

19. Aden, D. P., A. Fogel, S. Plotkin, I. Damjanov, and B. B. Knowles. 1979. Controlled synthesis of HBsAg in a differentiated human liver carcinoma-derived cell line. Nature (Lond.). 282: 615-616.

20. Morris, K. M., G. Goldberger, H. R. Colten, D. P. Aden, and B. B. Knowles. 1982. Biosynthesis and processing of a human precursor complement protein, pro-C3, in a hepatoma-derived cell line. Science (Wash. DC). 215: $399-400$

21. Hammer, C. H., G. H. Wirtz, L. Renfer, H. D. Gresham, and B. F. Tack. 1981. Large scale isolation of functionally active components of the human complement system. J. Biol. Chem. 256: 3995-4006.

22. Bing, D. H., J. M. Andrews, K. M. Morris, E. Cole, and V. Irish. 1980. Purification of subcomponents Clq, Clf, and $\mathrm{Cls}$ of the first component of complement from Cohn fraction I by affinity chromatography. Prep. Biochem. 10: 269-296.

23. Knowles, B. B., C. C. Howe, and D. P. Aden. 1980. Human hepatocellular carcinoma cell lines secrete the major plasma proteins and hepatitis B surface antigen. Science (Wash., DC). 209: 497-499.

24. Roberts, B. E., and B. M. Patterson. 1973. Efficient translation of tobacco mosaic virus RNA and rabbit globin 9s RNA in a cell-free system from commercial wheat germ. Proc. Natl. Acad. Sci. USA. 70: 2330-2334.

25. Rapp, H. J., and T. Borsos. 1970. Molecular basis of complement action. Appleton-Century-Crofts, New York.

26. Colten, H. R. 1972. Ontogeny of the human complement system: in vitro biosynthesis of individual complement components by fetal tissues. J. Clin. Invest. 51: 725-730.

27. Beatty, D. W., A. E. Davis III, F. S. Cole, L. P. Einstein, and H. R. Colten. 1981. Biosynthesis of complement by human monocytes. Clin. Immunol. Immunopathol. 18: 334-343.

28. Opferkuch, W., H. J. Rapp, H. R. Colten, and T. Borsos. 1971. Immune hemolysis and the functional properties of the second (C2) and fourth (C4) components of complement III. The hemolytic efficiency of human and guinea pig C2 and C4. J. Immunol. 106: 927-931.

29. Colten, H. R., and C. A. Alper. 1972. Hemolytic efficiencies of genetic variants of human C3. J. Immunol. 108: 1184-1187.

30. Harrison, R. A., and P. J. Lachmann. 1980. The physiologic breakdown of the third component of human complement. Mol. Immunol. 17: 9-20.

31. Laemmli, U. K. 1970. Cleavage of structural proteins during the assembly of the head of bacteriophage T4. Nature (Lond.). 227: 680-685.

32. Gorski, J. P., and H. J. Muller-Eberhard. 1978. Single chain C4 from human plasma. J. Immunol. 120: 17751776.

33. Gigli, I. 1978. A single chain precursor of $\mathrm{C} 4$ in human serum. Nature (Lond.). 272: 836-837.

34. Ooi, Y. M., and H. R. Colten. 1979. Biosynthesis and post-synthetic modification of a precursor (pro-C5) of the fifth component of mouse complement (C5). J. Immunol. 123: 2494-2498.

35. Patel, F., and J. O. Minta. 1979. Biosynthesis of a single chain pro-C5 by normal mouse liver mRNA: analysis of the molecular basis of C5 deficiency in AKR/J mice. J. Immunol. 123: 2408-2414.

36. Goldberger, G., L. P. Einstein, D. Bitter-Suermann, and H. R. Colten. 1981. Cell free translation and post-synthetic modification of guinea pig C2 and factor B. Fed. Proc. 40: 1067.

37. Ooi, Y. M. 1982. Biosynthesis of membrane and secreted factor B by mouse peritoneal macrophage. Mol. Immunol. In press. 